\title{
Balança de Traduções e Dominação Lingüística
}

\author{
Magdi Youssef'
}

a) Por que os árabes conhecem a literatura do Ocidente, ao passo que o Ocidente ignora a literatura árabe?

Em uma de suas definiçōes contemporâneas, a literatura comparada é o estudo da superação - ou do rompimento - dos limites entre uma literatura nacional com características e especificidades próprias e uma outra literatura nacional. Ou, por assim dizer, é o conhecimento que podemos ter da literatura de um outro cultural na própria língua desse outro, abrangendo sua imagem sócio-cultural, positiva ou negativa, tal como é representada em nossa literatura. Engloba-se aí, por exemplo, a imagem do africano nas literaturas européias, ou a imagem do Ocidente na literatura árabe, e assim por diante.

Nesse sentido, a literatura comparada é o estudo dos mecanismos e leis que determinam o grau de interação das várias literaturas nacionais, e a diversidade existente nas imagens dos po-

* Magdi Youssef, egípcio, é professor de literatura comparada na Universidade de Ayn Shams, no Cairo. Leciona na Irlanda e na Alemanha, onde, em 1965, inaugurou o curso de Líteratura Árabe Moderna e Contemporânea na Universidade de Colônia. Foi presidente da Associação Mundial para os Estudos de Interferência Cultural. Tem livros em alemāo, inglês, francês e irlandês, além do árabe (texto traduzido a partir do original árabe por Safa Alferd Abou Chahla Jubran e Mamede Mustafa Jarouche). 
vos, das culturas e das criaçōes literárias dos mais diversos povos, além das conseqüências finais em termos de influência sobre a postura dos povos do mundo contemporâneo uns em relação aos outros.

Talvez alguém observe que esse fato não raro ocorre às escâncaras no jornalismo e na maioria dos modernos veículos de comunicação, e até mesmo nos relatórios diplomáticos que os governos recebem de suas missões no Exterior. Porém, o que distingue isso tudo do objeto da literatura comparada está em que é possível que tudo isso faça o papel de matéria-prima para a criação de um escritor nalguma das formas de sua literatura nacional. Seja, por exemplo, o caso da literatura de viagem: ela não é senão a definição que a escola francesa tem da literatura comparada, ainda que ela tenha sido modificada através do criativo desenvolvimento dessa escola, operado a partir da década de 60 por um professor belga que dirige a cadeira de literatura comparada na Universidade de Aachen.

Esse professor, que, trabalhando na fronteira entre a Alemanha e a Bélgica, contribuiu diligentemente para o desenvolvimento da moderna escola francesa de literatura comparada, e para sua cristalização em bases teóricas distintas (embora seu fundamento tenha sido a cultura flamenga da Bélgica, onde ele tem sua origem e cujas causas nacionais ele defende), é Hugo Dyserink, verdadeiro fundador de uma escola de literatura comparada em âmbito internacional, e não apenas europeu e norte-americano. Há alguns anos, seu livro Introduçäo à literatura comparada foi traduzido e publicado na China Popular - agora aberta à literatura comparada. A teoria que Dyserink desenvolveu a partir da escola francesa foi a "imagologia", que significa o estudo da imagem de culturas, literaturas e civilizações e seu fugaz reflexo nas correspondentes literaturas nacionais, e o que isso implica em termos de glorificação mítica do outro cultural, além da admiração por sua literatura e por tudo que a ele esteja relacionado, ou, no 
caso inverso, a degradação da imagem das mais diversas culturas e sociedades em dada literatura nacional.

Agora, peço permissão ao leitor para abrir um parêntese, que logo será fechado, a fim de prosseguirmos em nosso assunto original: o caso que melhor representa o primeiro tipo de admiração pela cultura e literatura do outro é o da moderna literatura $\mathrm{e}$ crítica literária no Mundo Árabe diante da moderna literatura e crítica literária do Mundo Ocidental; quanto à melhor exemplificação para o caso contrário, é aquele que tem a ver com a imagem da literatura e cultura árabe contemporânea na maioria das literaturas européias, com exceção de alguma literatura espanhola e suas ramificaçōes latino-americanas, e isso porque os povos da América Latina e seus escritores passaram a interessar-se intensamente pelo conhecimento dos frutos criativos da literatura árabe moderna, estimulados pela imigraçāo árabe e pela história comum na Andalusia.

Quanto ao restante da Europa, lá não se reconheceu a literatura árabe moderna como objeto de estudo e pesquisa científica nos departamentos de estudos árabes até a metade da década de 60. Como poderia ser diferente, se até nas associaçōes ocidentais de literatura comparada e geral -que até hoje tratam não só a literatura árabe como também todas as literaturas do "Terceiro Mundo" com nāo pouco menosprezo e arrogância- fomos rotulados, conforme ocorreu na Associaçāo Internacional de Literatura Comparada, como "literaturas em desenvolvimento"? Em sua opinião, a "literatura universal" é, sem rival, a literatura européia ou de fonte européia.

Ainda que, nos densos programas de pesquisa que circulam em todos os seus congressos trienais, afete interesse por algumas literaturas do "Terceiro Mundo", a Associaçāo Internacional de Literatura Comparada dá exclusividade às literaturas africanas e norte-africanas em inglês ou francês! Uma simples espiadela na "balança de traduções" -equivalente da balança de pagamen- 
tos- de obras da literatura árabe moderna para as línguas européias e de obras das literaturas européias para o árabe é o mais eloqüente sinal do que estou pretendendo dizer: você não acreditaria, caro leitor, em que consiste, na realidade, a "divulgaçāo" da literatura árabe moderna no Ocidente. Eis, por exemplo, o famoso escritor suíço Dürenmatt: ao ser perguntado por um jornalista, no Cairo, sobre o que havia lido da literatura árabe contemporânea, respondeu que não havia lido nada, e que o máximo que ele conhecia de literatura árabe era o Livro das mil e uma noites.

Sendo este o caso de um escritor renomado, como será o conhecimento da literatura árabe entre o comum dos intelectuais ocidentais, para não dizer da população em geral?

b) A importância dos estudos contrastivos entre a língua árabe e as línguas estrangeiras para o fortalecimento da identidade nacional dos falantes do árabe.

Para esclarecer a questão a que me proponho, começarei por uma comparaçāo com a Irlanda, quando esta, por inteiro, ainda sofria a colonização inglesa. Nas escolas, as crianças irlandesas eram obrigadas a comunicar-se por meio da língua ingle$\mathrm{sa}$, e quem fosse surpreendido, pelo professor, falando a língua nativa -o irlandês- era obrigado a carregar no pescoço um "colar" de madeira, no qual se colocava uma marca, para, mais tarde, passar por um castigo corporal relativo ao número de marcas que aquele pedaço de madeira acusasse. O lamentável é que os professores que zelosamente aplicavam tal castigo eram, na maioria das vezes, eles mesmos irlandeses. Tinham a ilusão de que a sua adesão ao colonizador os auxiliaria a superar a estagnação e o atraso em que se encontravam. Esses mesmos irlande- 
ses que, no século passado, perderam um milhão de pessoas vitimadas pela fome, e outro milhão que imigrou para os Estados Unidos e Austrália.

A conseqüência disso: hoje, dos habitantes da república que se localiza ao sul, somente $5 \%$ conhecem a sua língua nativa - 0 irlandês. $E$, ao ser realizado, em 1987, um concurso para a escoIha das melhores traduçöes de poemas publicados em uma das línguas dos países membros do Mercado Comum Europeu, foi recusada a participaçāo da poesia expressa nessa língua. $\bigcirc$ motivo alegado foi que o irlandês não pertencia às línguas oficiais do Mercado, apesar de a Irlanda ser um membro deste, e de a língua irlandesa ser a língua oficial da República de Irlanda (ver Irish Times, 31/8/1987, p.7).

E quanto aos árabes? A maioria nem sabe que há na Irlanda uma república que lutou pela sua independência, por meio de um levante popular em 1916, contra o mesmo colonizador e na mesma data em que o povo egípcio o enfrentou. Há muitos árabes que ainda pensam que a Irlanda toda nảo passa de uma extensão da Grā- Bretanha!

O mecanismo de adesão ao dominador, por meio da identificação com sua língua e feição, foi o que empurrou a Irlanda a tal destino. A mesma ameaça paira sobre o futuro da língua árabe. Se o dominador de ontem era de fala inglesa, o dominador de hoje da economia dos povos é o Mercado Mundial, administrado em língua inglesa. Aliás, nada contradiz e confronta mais esse mercado do que as identidades culturais distintas que existem nas mais variadas sociedades, das quais as identidades culturais constituem a espinha dorsal. Isso porque a mercadoria, na era do domínio do Mercado Mundial, não reconhece nem deseja pátrias. Não obstante, os povos têm necessidade de tais mercadorias, não por causa das diferenças inerentes às várias identidades culturais e línguas nacionais - pois essa variedade alimenta a cultura humanística mundial mediante as trocas entre as culturas varia- 
YOUSSEF, Magdi. Balança das Traduçōes e Dominaçâo Lingüistica

das-, mas por causa dos valores de uso - materiais, intelectuais ou culturais - que circulam através da troca mercantil no Mercado Mundial.

Como fugir a essa situação? É verdade que todos os povos do planeta já atravessaram situações semelhantes. Mas o sofrimento dos nossos povos, recém-libertados da colonização, é muito mais intenso do que no hemisfério norte, onde se localiza a gerência do Mercado Mundial.

Será que a salvação estaria em abandonarem os árabes sua pele e identidade cultural, representadas basicamente pela língua árabe, adotando a língua ou as línguas vigentes naquele Mercado Mundial? Ou, ao contrário, em boicotá-las? E qual seria a saída, se é obvio que ambas as "soluçōes" só trarāo uma inevitável ruína? Qual a alternativa, então?

A alternativa sensata -em minha opinião- seria conhecermos e a seguir darmos a conhecer, às novas geraçōes de estudiosos árabes, os aspectos da diversidade cultural-social, literária e lingüística- existente entre eles e os outros povos de línguas e culturas distintas. $\mathrm{O}$ instrumento para essa diferenciação seriam os estudos contrastivos nos níveis língüístico, literário e sócio-cultural, a fim de lançar luzes não apenas sobre os fenômenos de "interferência lingüística", predominantes na sociedade árabe, mas também a fim de proporcionar-nos uma consciência com a qual poderemos nos defender dos mecanismos inconscientes de adesão à língua daqueles que imaginamos ou julgamos serem "melhores do que nós", mesmo dentro de nossa casa. Daí então, quando aprendermos uma língua estrangeira, européia ou não, não será com o sacrifício da nossa língua-mãe nem de nossa cultura árabe diferenciada, e sim com base numa consciência precisa da alteridade lingüística e cultural, evitando-se assim os mezanismos inconscientes de dominaçāo dos modelos lingüísticos e zulturais do "outro", na maioria das vezes com a nossa permissāo. 
Não há dúvida de que este projeto que estou sugerindo se baseia originalmente na hipótese de diferenciação de parâmetros entre as línguas e culturas variadas. Vale ainda ressaltar que, só no nível lingüístico, a simples comparação de elementos fonéticofonológicos e gramaticais já mostra diferenciação, embora se saiba que, para fazer um estudo contrastivo desses aspectos, é preciso observar, primeiramente, as mudanças e alteraçōes que aconteceram e acontecem na utilizaçāo prática da lingua árabe, para que se possa extrair delas -após análise crítica- uma consciência das formas de interferência lingüística e dos parâmetros sobre os quais se baseará tal estudo contrastivo.

O objetivo de tudo isto é o conhecimento científico preciso da identidade cultural árabe e o reforço de seu elemento principal, que é a língua árabe, no que se refere à sua diferenciação de outras identidades culturais e dos outros modelos lingüísticos e culturais. Eis, então, um apelo à tomada de consciência das alteridades lingüísticas e culturais e à recusa da dominação. 